\title{
Die verband tussen doop en lidmaatskap
}

\section{van die kerk}

WA Dreyer

Tydelik-deeltydse dosent: Departement Kerkgeskiedenis

Universiteit van Pretoria

\begin{abstract}
The relationship between baptism and membership of the church

This article examines the relationship between baptism and membership of the church. The author's main thesis is that baptism signifes the wity with Christ, and as such unity with the body of Christ (the church). Research has shown that baptism exists in different religions, cults and sects as an imitiation rite. This forms the background to the New Testanent's presentation of baps: ism as (inter atta) an initiation rite. This article examines not only these baptisin rites, but also the Wfferent netaphors in the New Testament concerned with bapism as initiation. The history of boptism in the church and the Way baptism functions in the Reformed tradition, in terms of ehurch polity and nembership of the church, are also examined.
\end{abstract}

\section{INLEIDING}

Hierdie artikel word met graagte aan proff $\mathrm{M} J$ du P Beukes en L J S Steenkamp opgedra. Hulle was albei ten nouste by die kinders van die kerk betrokke, prof Beukes op die gebied van die kategese en prof Steenkamp op die gebied van die onderwys. Dit was my voorreg om op verskillende sinodale rade met hulle saam te werk, en iets te ervaar van hulle passie vir die geloofsopvoeding van die kind in die kerk.

Dit is hierdie gesprekke en besluite van sinodale rade wat daartoe aanleiding gegee het dat die Algemene Kerkvergadering van die Nederduitsch Hervormde Kerk van Afrika versoek is om 'n studie oor die kind in die kerk te doen. Een van die studieopdragte was om die verband tussen doop en lidmaatskap van die kerk na te vors. Die voorhande studiestuk is die resulaat van dié opdrag van die AKV. 
Hiermee erken die outeur baie graag en met dankbaarheid die bydraes van dr $\mathbf{P}$ J van Staden (Ned Herv Gem Philadelphia), ds F H van der Merwe (Ned Herv Gem Benoni), prof A P B Breytenbach (Fakulteit Teologie UP), prof $H$ G van der Westhuizen (emeritus dosent van die HTO te Klipdrif) en prof A D Pont (emeritus dosent van UP). Die persone het almal moeite gedoen om die aanvanklike memorandum grondig te bestudeer, en kommentaar daarop te lewer. Meeste van die kommentaar is (met vermelding) in hierdie finale studiestuk verwerk, maar die outeur aanvaar in die laaste instansie die verantwoordelikheid vir die inhoud daarvan.

\subsection{Probleemstelling}

Die basiese (kerkregtelike) probleem waarom dit in hierdie artikel gaan, is: Wanneer is ' $n$ mens lidmaat van 'n kerk? Binne die Afrikaanse gereformeerde kerke bestaan die algemene opvatting dat ' $n$ mens eers werklik lidmaat van ' $n$ kerk is as jy belydenis van geloof afgelê het. Die tese van hierdie artikel is dat dié beskouing nie Skriftuurlik is nie, en strydig met die kerkbegrip van die Nederduitsch Hervormde Kerk is. As daar na 'n aanduibare geleentheid van opname in 'n kerk gesoek moet word, moet daar eerder na die doop gekyk word. Selfs dit is nie 'n eenvoudige saak nie.

Daar was uiteenlopende standpunte tussen die medewerkers oor die verstaan van die doop. Een van die kernsake waaroor verskil is, is die vraag of die doop net 'n teken of simbool is van byvoorbeeld die inlywing in Christus, en of daar meer gebeur by die doop as dat dit 'n blote teken is. Sonder twyfel moet 'n mens raaksien dat die doop in sigself geen betekenis het nie, nog minder dat die doop betekenis het omdat die kerk dit bedien. Dit sou die Rooms-Katolieke Kerk se standpunt handhaaf, want die Rooms-Katolieke Kerk gaan van die standpunt uit dat die doop die heil bemiddel, omdat die kerk dit bedien. Die Rooms-Katolieke Kerk gee dus aan die doop waarde.

Binne die Hervormde denke was dit nog altyd duidelik dat die doop ons heenwys na Jesus Christus, en dat die heil deur Christus gebring word. Dit moet onverkort gehandhaaf word, anders verval die kerk in 'n sakramentalisme. Die doop wys ons op dit wat Christus gedoen het, en in daardie sin is die doop 'n teken of simbool van dit wat in Christus gebeur het. Maar tegelykertyd ontkom 'n mens nie aan die indruk nie, dat die Skrif (en die belydenisskrifte en formuliere) veel meer van die doop maak as net 'n uiterlike en simboliese handeling. Die indruk wat geskep word, is dat by die doop inderdaad iets gebeur - byvoorbeeld die inlywing in die liggaam van Christus. Dit lyk of dit nie 'n of-of situasie is nie, maar 'n en-en. Die 
doop is ' $n$ uiterlike teken van dit wat reeds in Christus plaasgevind het, en inderdaad gebeur daar iets by die doop.

Hopelik sal dit in die volgende uiteensetting duidelik word dat die doop baie meer tot reg moet kom, veral in die Nederduitsch Hervormde Kerk. Dit is my mening dat die oorbeklemtoning van die doop as simbool, die betekenis van die sakrament laat skade lei het. Dat die doop wesenlik belangrik is vir ons verstaan van die Nederduitsch Hervormde Kerk en lidmaatskap van die kerk, bestaan min twyfel.

\section{VOORLOPERS VAN DIE CHRISTELIKE DOOP}

Daar is talle voorbeelde in die geskiedenis, ook in die Nuwe-Testamentiese tydperk, van godsdienste en groepe wat een of ander vorm van doopritus gehad het. Die doopritus het normaalweg as kultiese reiniging gedien, maar tweedens ook as inlywing in die bepaalde geloofsgemeenskap. In hierdie studie word net na dié wat 'n direkte of indirekte invloed op die Christelike doopraktyk uitgeoefen het, verwys:

\subsection{Rituele wassing/reiniging in die Ou Testament}

Die Christelike doop is op ' $n$ indirekte wyse deur die rituele wassinge wat in die $\mathrm{Ou}$ Testament voorgeskryf word, beinvloed (Van't Spijker 1983:15). Daar is byvoorbeeld van die priesters verwag om 'n rituele wassing (reiniging) te ondergaan voordat hulle die tent van ontmoeting kon binnegaan om hulle diens daar te lewer (Eks 29:4). Dieselfde het ook vir die Leviete gegeld (Num 8:6-7). Selfs die volk Israel moes hulle ritueel reinig voordat hulle aan die erediens kon deelneem (Lev 15). So is daar nog talle ander voorskrifte waar rituele wassing voorgeskryf word vir besondere gevalle (melaatses, vroue en so meer). Hieragter lê die teologiese gedagte dat mense nie sondermeer in die teenwoordigheid van God kan kom nie, maar eers gereinig moet word van hulle sonde en onreinheid voordat hulle dit in die teenwoordigheid van die heilige God kan waag. Israeliete kon alleen deel van die kultiese geloofsgemeenskap wees, as hulle die kultiese reiniging met water ondergaan het. Die reinigingsrite het die gereinigde die voorreg gegee om in gemeenskap met God te tree.

Die rituele wassing het nie net met die tempeldiens en die erediens te doen gehad nie. Ook in die algemene lewe was dit van mense verwag om hulle te reinig, omdat God se teenwoordigheid nie net tot die tempel beperk was nie, maar God is teenwoordig in die totale lewe van die mens. Daarom lees mens byvoorbeeld in 2 
Samuel 12:20 dat Dawid homself gewas het nadat hy gehoor het dat die kind wat hy by Batseba verwek het, gesterf het. Nadat hy hom gereinig het, kon hy weer met sy taak as koning en die alledaagse lewe voortgaan.

Dit is ook duidelik dat hierdie rituele wassing nie in sigself enige betekenis gehad het, as dit nie ook met die ware gesindheid van bekering, gehoorsaamheid en geloof gepaard gegaan het nie (Jes 1:16-17). Tegelykertyd is dit ook só dat die rituele reiniging met water met die gawe van die Heilige Gees verbind word (Eseg 36). Daar was veral by die profete die besef dat die ware reiniging van God kom, en nie deur die water as sodanig geskenk word nie (Sag 13:1-2).

\subsection{Die Joodse besnydenis}

Die Christelike doop is ook deur die Ou-Testamentiese besnydenispraktyk beïnvloed (Van't Spijker 1983:28-29). In die Ou Testament, is die besnydenis en verbond onlosmaaklik aan mekaar verbind (vgl Gen 17:1-27). Die besnydenis het gegeld as die verbondsteken. Deur die teken is gelowiges voortdurend daaraan herinner dat hulle aan God behoort, en in 'n bepaalde verbondsverhouding met God staan. Tog het die profete herhaaldelik daarop gewys dat die besnydenis nie maar outomaties God se seën aan die besnedene laat toekom nie. Daar moet ook 'n "besnydenis van die hart" wees (Jer $4: 4 ; 6: 10)$.

In die tye waar die Jode onderdruk is deur vreemde owerhede, het die besnydenis ook die vorm van ' $n$ belydenis aangeneem. In die tyd van Antiochus IV. (175163 v C), is die Jode met die dood gestraf as hulle hulle kinders besny het. Talle ouers het eerder gesterf, as om hulle kinders nie te laat besny nie. Dit het ook praktyk geword om by die besnydenis, die kind se naam aan hom te gee. As mens in gedagte hou hoe belangrik ' $n$ naam in die antieke kulture was, kan 'n mens die afleiding maak dat die kind by die benydenis eers werklik 'n "persoon" geword het met identiteit - 'n identiteit wat grootliks bepaal word deurdat hy in 'n verbondsverhouding met God staan (Van't Spijker 1983:28-29).

In 'n gedeelte soos Kolossense 2:11-12 word daar 'n direkte verband tussen die Ou-Testamentiese besnydenis en die Nuwe-Testamentiese doop gelê. Daar word die gemeente in Kolosse daarop gewys dat hoewel hulle nie liggaamlik besny is nie, hulle die "geestelike" besnydenis ontvang het deurdat Jesus Christus al hulle sondes weggeneem het. Hierdie "besnydenis" het by die doop plaasgevind. In lyn met die 
denke oor die besnydenis, is dit ook so dat die gedoopte by die doop ware identiteit vind, deurdat die gedoopte 'n nuwe mens in Christus word.

Daar word dikwels beswaar gemaak teen die gedagte dat die besnydenis enige betekenis vir die doop kan hê. Hierdie besware kan gegroepeer word onder drie hoofde:

- Die besnydenis het net betekenis vir die natuurlike volk Israel;

- die besnydenis was net bedoel vir die manlike geslag en

- die besnydenis is die resultaat van 'n natuurlike geboorte en nie die resultaat van geloof en wedergeboorte nie.

Hierdie argumente hou nie rekening daarmee dat daar reeds in Genesis 17 daarop gewys word dat die besnydenis vir meer as die volk Israel bedoel is nie, maar vir alle nasies. Vrouens was vanselfsprekend, deur hulle vaders en eggenotes, deel van die verbond. Die Jode het in hulle sending en proselietmakery dit ook baie duidelik bewys dat die Ou-Testamentiese geloofsgemeenskap nie uitsluitlik bepaal is deur die natuurlike vereistes van afstamming, geboorte en volkskap nie. Saam met besnydenis was die onderrig in die ware godsdiens en die volharding in die geloof van kardinale belang. Dit was ook moontlik dat 'n gebore Israeliet deur sy ongeloof buite die geloofsgemeenskap te staan kon kom (Paulus se argument in Rom 9).

Hoe dit ook al sy: Dit is baie duidelik uit die Nuwe Testament, dat die NuweTestamentiese skrywers die Christelike geloof gesien het as voortvloeiend uit die OuTestamentiese geloof, soos 'n nuwe loot wat op 'n ou stam geënt is (vgl Rom 9-11). Daarom kan Christene ook kinders van Abraham genoem word (Rom 4). Dit is gewoon onwetenskaplik en onhistories om te beweer dat die Ou Testament, en die gebruike van die Ou Testament, geen invloed op die vroeë Christelike gemeenskap se denke uitgeoefen het nie. In afdeling 2.4 van hierdie studie sal verder aandag gegee word aan die hele saak van die verbond en die doop.

\subsection{Die dooppraktyk van die Qumrangemeenskap}

Die gemeenskap by Qumran het besonder baie aandag aan die rituele wassing gegee. In die dokumente wat van hulle oorgebly het, word uitgespel op watter voorwaardes mense die rituele wassing kon ondergaan. Die wassing was niks anders as 'n doop 
nie, omdat die voorskrifte bepaal het dat die persoon wat gewas word, geheel en al onder die water moes ingaan. Die liggaam is volledig bedek met water. Die lidmate van die Qumran gemeenskap het hulleself herhaaldelik gereinig. Dit was dus 'n voortdurende proses van bekering, reiniging en deelname aan die geloofsgemeenskap. By die Qumran gemeenskap het die gedagte baie sterk geleef dat die doop as reinigingsrite op sigself geen betekenis het, as dit nie gepaard gaan met ' $n$ ware geloof en bekering nie. Hulle het ook die rol van die Heilige Gees baie sterk beklemtoon in die reinigingshandeling (Van't Spijker 1983:18). Op hierdie wyse het hulle baie sterk by die Ou-Testamentiese profete se uitsprake oor reiniging aangesluit en dit in hulle dooppraktyk sigbaar laat word.

In die Reël van die gemeenskap, een van die dokumente van Qumran wat behoue gebly het, kom ' $n$ verdere saak na vore wat van belang is: Die Qumrangemeenskap het die gereelde rituele wassings (dope) verstaan as 'n deurlopende hernuwing van die verbond tussen God en mens. Dit het ook 'n baie sterk eskatalogiese dimensie aan hulle doop gegee. Die eskatalogiese stryd tussen en lig en duister het beteken dat die kinders van die lig hulle voortdurend aan God moes toewy, en die doopritus was tekenend van hulle toewyding aan God.

Daar moet ook onderskei word tussen die gereelde wassings (dope) wat by Qumran plaasgevind het, en die eerste wassing (doop) wat 'n lidmaat ondergaan het. Die eerste wassing was net die eerste in hele reeks wassings, maar het baie duidelik die betekenis van 'n inisiasierite gehad. Dit kon net plaasvind na grondige voorbereiding, bekering en toewyding aan God. Die noviet word deur die eerste doping in die gemeenskap van Qumran opgeneem, maar dit was ook simbolies van die gedoopte se oorgang van die ou, sondige lewe na die die nuwe lewe van gehoorsaamheid aan God. So is die reiniging van sonde en die inisiasie in die geloofsgemeenskap, direk aan mekaar verbind. Dit is interessant en opvallend dat die noviet nie deur iemand anders gedoop is nie, maar homself in die water ingedompel het - wat nie vreemd is nie, aangesien die Ou-Testamentiese rituele wassings ook gewoonlik deur die persoon self uitgevoer is.

\subsection{Die Joodse proselietedoop}

Die woord proseliet kom van die Septuagint se vertaling van ger, en wat in die Afrikaanse Bybel met die woord vreemdeling weergegee word. Daar is in die Ou Testament bepaalde voorskrifte hoedat die vreemdeling in die poorte behandel moes 
word. Hierdie vreemdelinge (proseliete) was gewoonlik vlugtelinge as gevolg van oorlog, geweld of hongersnood. Die Israeliet moes aan hulle barmhartigheid bewys. Een van die belangrikste ontwikkelings in die voorchristelike Judaïsme is dat die betekenis van die woord ger/proseliet verander het van vreemdeling na bekeerling. In die Mishna word dit duidelik dat proseliete as bekeerlinge beskou word, mense wat oorgegaan het na die Joodse geloof en ingelyf is in die Joodse geloofsgemeenskap (Pope 1985:921). In Matteus 23:15 word, by monde van Jesus, verwys na die Fariseërs wat oor land en see reis om proseliete (bekeerlinge) te maak.

Daar bestaan 'n meer direkte verband tussen die Christelike doop en die Joodse proselietedoop (Van't Spijker 1983:19). Dit word algemeen aanvaar dat die die praktyk om Joodse proseliete te doop, reeds in die tyd van Christus bestaan het, en dat dit inderdaad 'n ouer vorm van doop verteenwoordig as die Christelike doop. Die oudste skriftelike getuienisse wat iets sê oor die proselietedoop, dateer egter uit die jare 80-90 n C, waar die rabbynse skole van Hillel en Shamai in debat met mekaar was oor die verhouding tussen die besnydenis en die proselietedoop. Verder het die skool van Shammai geleer dat die proseliet op die dag voor die Joodse paasfees homself moet doop, en dan aan die paasfees en paasoffer moet deelneem.

'n Paar jaar later, omstreeks 94 n C, verskyn die geskrif van Epictetus waarin hy handel oor die wyse waarop 'n heiden kan oorgaan na die Jodedom. Daarin vermeld hy dat hy slegs as egte Jood sal geld, indien hy gedoop is. Dit is verder opvallend dat die volwasse proseliet, sowel as sy kinders, in die rivier moes ingaan om gedoop te word. As 'n vrou egter verwagtend is wanneer sy gedoop word, is die ongebore kind ook beskou as gedoop, en as 'n ware Jood. Hoewel hierdie rabbynse dokumente redelik laat is, is hulle in dieselfde tyd geskryf as baie Nuwe-Testamentiese geskrifte. Geleerdes is dit redelik eens dat hierdie bespreking van die proselietedoop verwys na 'n praktyk wat lank tevore reeds in aanvang geneem het (Pope 1985:930).

Dit was interessant genoeg deel van die rabbynse tradisie dat die Israeliete, voordat hulle die wet by Sinai ontvang het, gedoop is. Dit word gegrond op ' $n$ interpretasie van Eksodus 24:8, waar gepraat word oor die besprenkeling met die bloed. Geen sodanige besprenkeling (vlg Joodse gebruik) kon plaasgevind het as daar nie eers 'n rituele wassing vooraf plaasgevind het nie. Soms word die deurtog deur die Rooi See ook in die rabbynse literatuur as 'n doping beskou - dieselfde gedagte wat die apostel Paulus in 1 Korintiërs 10:1-2 uitspreek. 
Dit is duidelik dat die proselietedoop in die eerste plek om 'n inisiasie of inlywing gegaan het. Waar die klem by Qumran op die reiniging val, val dit by die Joodse dooppraktyk op die inlywing van die proseliet in die Joodse geloofsgemeenskap.

\subsection{Die doop van Johannes die Doper}

Nog een van die belangrike voorlopers van die Christelike doop, is die dooppraktyk van Johannes die Doper. In sy geval het die klem by die doophandeling (soos by Qumran) op die ware gesindheid van bekering en gehoorsaamheid geval, met die doop as teken van die reiniging van die sonde. Maar tegelykertyd vertel die evangelies vir ons dat Johannes die Doper die koms van God se koninkryk aankondig - en dan dien die reiniging weereens as voorwaarde vir toegang tot die koninkryk van God. Die doop van Johannes dien dan nie as inlywing in een of ander godsdienstige groep nie, maar as teken van die inlywing in die koninkryk van God, die partisipasie aan die koninkryk van God (Van't Spijker 1983:22). Die doop van Johannes is (soos by die Qumrangemeenskap) uit en uit eskatalogies gerig.

Johannes se optrede was voorbereidend van aard gewees. Daarom was sy doop in 'n sekere sin voorbereidend vir die koms en optrede van Jesus self. Die evangelies tref onderskeid tussen die doop van Johannes, en die doop wat Jesus sou instel (Joh 1:19-34; Mt 3:11). Dit is dus nie so maklik om 'n direkte verband tussen die doop van Johannes, en die doop wat Jesus sou instel, te lê nie - behalwe vir die feit dat die doop van Johannes na Jesus heenwys (Joh 1:31), en die doop wat Jesus ingestel het, dieselfde doen. In beide doophandelinge gaan dit om die partisipasie aan die koninkryk van God, beide gaan om die heilswerk van Jesus Christus.

\section{DIE VERBAND TUSSEN DOOP EN LIDMAATSKAP VAN DIE KERK IN DIE NUWE TESTAMENT}

Uit bogenoemde paar opmerkings word dit duidelik dat toe Jesus begin het met sy openbare optrede, die doop van mense reeds 'n bekende praktyk was. Vanuit die $\mathrm{Ou}$ Testament was die wassing/reiniging van mense 'n bekende gedagte. Sommige Fariseërs in Jesus se tyd het oor land en see gereis om proseliete te maak, en hulle het waarskynlik 'n uitgebreide dooppraktyk aan die gang gehad. Tegelykertyd was daar die Qumrangemeenskap en Johannes die Doper wat bepaalde dooppraktyke gehad het. 
Hierdie drie belangrike godsdienstige groeperings, tydgenootlik aan Jesus en die vroeë kerk, het dus bepaalde dooppraktyke gehad. Daarom is dit ook nie vreemd dat die heel vroegste Christene begin het om te doop nie (vgl Hand 2), in die vaste vertroue dat dit die opdrag van die Here Jesus self was om te verkondig, te doop en te leer (Matt 28:19-20).

Die Nuwe Testament praat op baie maniere oor die doop. Daar kan egter drie hoofgedagtes onderskei word (vgl König 1995: 6-29): Die eerste hoofgedagte is dat dit in die Christelike doop om die reiniging en afwassing van sonde gaan; die tweede hoofgedagte is dat die doop ' $n$ teken is van die inlywing in die kerk; en die derde hoofgedagte is dat die doop teken is van die gedoopte se vervulling met die Heilige Gees en opstanding tot ' $n$ nuwe lewe. Dit is belangrik om daarop te let dat hoewel hierdie hoofgedagtes onderskei kan word, dit tog nie in totale isolasie van mekaar funksioneer nie. Soos reeds bo aangedui, dien die afwassing van die sondes dikwels as voorwaarde vir die inlywing in die geloofsgemeenskap. Inlywing in die kerk is ook ondenkbaar sonder die wedergeboorte, opstanding tot die nuwe lewe en die vervulling met die Heilige Gees.

Vir die doeleindes van hierdie studie, word daar net na een hoofgedagte gekyk, en dit is die verband wat tussen die doop en lidmaatskap van die kerk bestaan. In die verband moet daar na vier verskillende beelde gekyk word:

- die doop as vereniging met Christus;

- die doop bevestig dat die gedoopte die eiendom van Christus is;

- die doop as inlywing in die liggaam van Christus;

- die doop bevestig dat die gedoopte deel is van die verbondsgemeenskap.

\subsection{Die doop bevestig dat die gedoopte die eiendom van Christus is}

Daar word verskeie kere in die Nuwe Testament verwys na die doop in die Naam van Jesus (Hand 2:38; 8:16; 10:48; 19:5). Daar word ook eenmaal verwys na die doop in die Naam van die Vader, Seun en Heilige Gees (Matt 28:19). Hoewel hierdie doopformule nie uitdruklik by Paulus voorkom nie, is dit duidelik geïmpliseer in 1 Korintiërs 1:13 en 15, en word dit aanvaar dat Paulus daarmee bekend was as die gebruiklike doopformule van die vroeë Kerk [Pelser s a:38]. 
Om te verstaan wat dit beteken om in die Naam van gedoop te word, moet 'n mens gaan kyk na voorbeelde in die Ou Testament. Verskeie teoloë soos Lohse, Goppelt, Schnackenburg en Bietenhard aanvaar dat die formule die ekwivalent van die Hebreeuse lešem (of bešem) is. Ons lees byvoorbeeld in 2 Samuel 12:28 (vgl Hebreeuse teks - in die NAV kom dit nie duidelik na vore nie) dat Dawid se naam oor Rabba uitgeroep moet word, sodat dit duidelik kan word dat die stad sy eiendom is, en dat hy regeer oor die stad. Omdat die Naam van die Here oor Israel uitgeroep is, behoort Israel aan die Here (2 Kron 7:14). Op grond hiervan maak König die afleiding dat wanneer die Naam van God uitgeroep word oor iemand, daardie persoon God se eiendom word:

\begin{abstract}
Wanneer iemand dus "in die Naam van Jesus Christus" gedoop word, beteken dit ook dat hy of sy aan Christus behoort, sy eiendom word, dat Hy volle gesag oor hulle lewe het. Om onder Christus se gesag te kom, beteken om uit die mag van die sonde en die Bose verlos te word, om vrygemaak te word tot 'n nuwe lewe. Die doop plaas ons dus onder die bevryende gesag van Jesus Christus.
\end{abstract}

(König 1995:8)

A P B Breytenbach wys in sy kommentaar daarop dat daar onderskei moet word tussen iets in die naam van iemand te doen, iemand se naam oor iets uit te roep en derdens om iemand op die naam te roep. In die eerste geval beteken dit dat jy met volmag van die bepaalde persoon iets doen (Deut 18:5-22/Hand 3:6); in die tweede geval beteken dit dat 'n kooptransaksie beklink word en daar 'n verwisseling van eienaarskap plaasvind; in die derde geval beteken dit om beheer te kry oor iemand. Vanuit hierdie perspektief sou die doopformule van die Nuwe Testament (doop in die Naam van die Vader, die Seun en die Heilige Gees) beteken dat (1) die doop met die volmag van God bedien word; (2) dat die dopeling die eiendom van God is en (3) dat die dopeling onder beheer van God staan.

P J van Staden wys in sy kommentaar daarop dat hoewel daar verskil van mening onder Nuwe-Testamentici oor die betekenis van die formule in die Naam van bestaan, heelwat tog aanvaar dat dit die Griekse weergawe van die Hebreeuse lešem is. Hy verwys verder na Schnackenburg en Lohse wat daarop gewys het dat dit 
grammatikaal as doelsin kan funksioneer - die naam van Christus word dan oor die dopeling uitgeroep om hom of haar sodoende aan Christus te verbind.

Daar bestaan ook die opvatting dat die term in die Naam van geen rol as sodanig speel nie, en dat die term sinoniem is met die term en Christo. In die geval sou dit beteken dat die doop die heil wat Christus verwerf het, vir die dopeling toegeëien word. Die meeste stem saam dat om onder die aanroeping van die Naam van die Vader, Seun en Heilige Gees gedoop te word, beteken dat die dopeling aan God verbind word, as sy eiendom geproklameer word en onder sy beskerming te staan kom. Hierdie opvatting word gesteun in teksgedeeltes soos 2 Korintiërs 1:21; Efesiërs $1: 13 ; 4: 30 ; 1$ Johannes $2: 20-27$. In hierdie teksgedeeltes word dit duidelik dat die doop onder andere 'n geleentheid is waar die Heilige Gees die gedoopte vervul, en die gedoopte dan (deur die Gees) geproklameer word as God se eiendom.

Hierdie beeld, naamlik dat die gedoopte die eiendom van Christus is, het betekenis vir lidmaatskap van die kerk, want die kerk is die eiendom van Christus. Die kerk bestaan uit mense wat aan Christus behoort, mense wat $\mathrm{Hy}$ aan die kruis vrygekoop het van die mag van die sonde en die dood. Hulle staan nou nie meer onder die heerskappy van Satan nie, maar onder die heerskappy van Christus. Die gevolgtrekking is dat die gedoopte, as eiendom van Christus, deel is van die kerk. Die Nederlandse Geloofsbelydenis formuleer dit soos volg in Artikel 34: Deur die doop word ons in die kerk van God opgeneem en van alle gelowiges en vreemide godsdienste afgesonder om heeltemaal sy eiendom te wees en sy merkteken en vaandel te dra (NHKA 1983:156).

\subsection{Die doop as vereniging met Christus}

Hoewel daar baie ooreenkomste is tussen die vereniging met Christus en die vereniging met die liggaam van Christus, kan 'n mens ter wille van die duidelikheid tog tussen die twee beelde onderskei. Vereniging met Christus beteken dat die gedoopte deel het aan alles wat Christus gedoen het, naamlik sy verlossingswerk aan die kruis en sy opstanding (König 1995:9). Romeine 6:1-14 sê dat die dopeling in Christus ingedoop is, en met Christus verenig is. Die dopeling sterf saam met Christus, en staan saam met Christus op tot 'n nuwe lewe. Sy sondige natuur word gekruisig, en die nuwe mens staan op tot 'n nuwe lewe (wedergeboorte). Soos Christus uit die dood deur 'n heerlike magsdaad van God opgewek is (Rom 6:4), so word die dopeling deur 'n heerlike magsdaad van God opgewek tot 'n nuwe lewe, word hy of sy verenig met 
Jesus Christus en sy heilswerk. Wat by die doop gebeur, is dus God se kragtige werk, nie die resultaat van menslike inspanning nie.

Die gedoopte is dood vir die sonde - dit staan in Romeine 6 as indikatief, en nie as imperatief nie. Daarom kan 'n baba gedoop word, en deur die magsdaad van God saam met Christus sterf en saam met Hom opstaan tot 'n nuwe lewe. Maar tegelykertyd word die indikatief 'n imperatief aan die gedoopte - dat hy of sy moet word wat hy of sy reeds in Christus is - 'n nuwe mens. Daarom word die doop opgevolg met verkondiging, onderrig (kategese) en pastorale bearbeiding. Die gedoopte word dus binne die gemeenskap van die gelowiges deur die verkondiging begelei om te word wat hy of sy reeds in Christus is. Daarom rig die doop voortdurend 'n appèl aan die gedoopte om te breek met sonde en ongeloof, en eerder 'n nuwe lewe in en deur Christus te leef. Die gedoopte kom onder die mag van die Heilige Gees, en die Heilige Gees lei die gedoopte tot geloof en bekering. Op daardie wyse maak die Heilige Gees ons wat reeds in Christus is - nuwe mense wat dood is vir die sonde, maar lewe vir God.

In Romeine 5:12-19, die gedeelte voorafgaande aan die doopteks in Romeine 6, kom die korporatiewe betekenis van Christus se heilswerk baie duidelik na vore. Daar word gesê dat die sondaar mens in Adam ingesluit is, maar ook in Christus ingesluit is. Die mens is in Adam en in Christus inbegrepe (Konig 1995:10). Mense kry deel aan Adam op grond van hulle sonde, en deel aan Christus deur die doop en die werking van die Heilige Gees wat in ons geloof wek. Die Heilige Gees verenig ons met Christus, sodat ons korporatief ingesluit is in sy heilswerk.

\subsection{Die doop as inlywing in die liggaam van Christus (die kerk)}

As die gedoopte met Christus verenig is, volg dit vanself dat gedooptes ook met mekaar verenig is. Die Skrif vermeld op verskillende plekke dat die kerk die liggaam van Christus is. As die doop die teken daarvan is dat die gedoopte in die liggaam van Christus ingelyf is, beteken dit dat die doop die geleentheid is wanneer ons sigbaar in die kerk ingelyf word. Daar vind ' $n$ vereniging met Christus en met die medegelowiges plaas. Die doop (soos die nagmaal) het dus besondere betekenis vir die eenheid van die kerk (Ef 4:4-6). Die doop is die universele identifikasie met en inlywing in die liggaam van Christus. Daarom praat die Engelse kerklike wêreld nie van "baptise" nie, maar van "christening". Daar lê in hierdie woordgebruik iets van die besef dat die doop die universele merkteken van 'n Christen is. In 1 Korintiërs 12:13 lees 
ons: Want ons is almal ook deur een Gees gedoop tot een liggaam (OAV). Die Nuwe Afrikaanse Vertaling het die teks verkeerd vertaal (König 1995:12), deurdat oorsaak en gevolg omgekeer is. Die NAV vertaal dit asof lidmaatskap van die kerk lei tot die doop, terwyl dit die doop is wat ons almal een liggaam maak.

P J van Staden wys daarop dat die belangrike vraag in 1 Korintiërs $12: 13$ is of

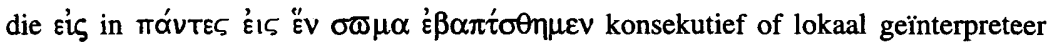
moet word, dit wil sê of die doop van verskillende mense die kerk konstitueer, en of die dopeling in die reeds bestaande kerk "ingedoop" word? Van Staden kom tot die gevolgtrekking dat laasgenoemde die mees aanvaarbare interpretasie is, aangesien die liggaam van Christus lank reeds bestaan. Die konteks van 1 Korintiërs 12:13 beklemtoon dat die doop as inlywing dien in die reeds bestaande liggaam van Christus.

Die Gees lyf ons by die doop in die liggaam van Christus, in sy kerk, in. Van vroeg af was die doop beskou as die inlywing van die dopeling in die gemeenskap van mense wat Jesus as Christus en Here bely. Die doop is die openlike, en amptelike, toetrede tot die kerk van Christus. Daarom sê die doopformulier dat wanneer ons in die Naam van die Heilige Gees gedoop word, Hy in ons wil woon en ons tot lede van Christus wil maak (Diensboek NHKA 1987:56). Uit die konteks van die formulier word dit duidelik dat die inlywing nie eers plaasvind wanneer ons belydenis van geloof aflê nie, maar dat dit de facto by die doop plaasvind.

\subsection{Die doop as teken van die verbond}

Talle kerke in Suid-Afrika het min of geen waardering vir die verbondsmatige begronding van die doop nie (Pont s a:5), en word die verbond met kerklike koudheid en formalisme geassosieer (König 1995:66). Daar word die beskuldiging gemaak dat waar die verbond as basis van die doop funksioneer, kinders outomaties salig word èn nooit tot bekering kom nie. Dit is opvallend dat die kerke wat die kinderdoop teenstaan, tegelykertyd die verbond teenstaan. Ook vanuit die nuwere hermeneutiek is daar heelwat kritiek teen 'n verbondsteologie, asof dit die enigste teologiese paradigma sou wees waarbinne die doop funksioneer (Venter 1984:66). Tog kan 'n mens nie die doop sonder die verbond verstaan nie (König 1995:66; Venter 1984:67). Binne die Calvinistiese denke is die verbond ' $n$ baie belangrike bousteen van die teologisering oor die doop. Breytenbach wys in sy kommentaar daarop dat dit nie al manier is om oor die doop te dink nie, en dat die doop nie staan en val by die verbond 
nie. Daarteenoor beweer sommige teoloë dat die doop wel staan en val met die leer van die genadeverbond (Pont $\mathrm{s}$ a:16).

Wat is ' $\mathrm{n}$ verbond? ' $\mathrm{n}$ Verbond kan onder andere beskou word as 'n bepaalde verhouding wat daar tussen God en mens bestaan (König 1995:67; Venter 1984:66; Pont $s$ a:5). Daar is 'n groot variasie van verbonde in die Ou Testament. Ons lees van verbonde wat die Here gesluit het met Noag, Abraham, Joshua, die volk Israel, Dawid en Nehemia. In die Nuwe Testament word 'n nuwe verbond in Jesus Christus gesluit (Matt 26:28; Luk 22:20). In elkeen van hierdie situasies funksioneer die verbond verskillend. In die Ou-Testamentiese verbonde word daar dikwels sekere beloftes gemaak, en ontstaan daar ook sekere verpligtinge. Binne hierdie raamwerk van wedersydse beloftes en verpligtinge, kom daar ' $n$ verhouding tussen God en mens tot stand. In die Nuwe-Testamentiese verbond ontvang die mens die belofte van verlossing op grond van Jesus se offer aan die kruis. Tegelykertyd is die dood en opstanding van Jesus 'n appèl tot die mens om op 'n sekere manier te leef. Jesus Christus bring ' $n$ nuwe verhouding tussen God en mens tot stand. Dit is ' $n$ verbond.

Dit is belangrik om daarop te let dat dit God is wat die inisiatief neem om met 'n mens of ' $n$ volk of ' $n$ gesin 'n verbond sluit. Die feit dat die oorsprong van 'n verbond by God gevind word, gee daaraan 'n vastheid, 'n betroubaarheid. Dit sê dat die verhouding tussen God en mens nie gebou word op menslike willekeur of ontrouheid nie, maar op God se getroue onderhouding van God se beloftes. Dit is veral duidelik wanneer die nuwe verbond in Jesus Christus tot stand kom. Dit het dié implikasie dat die volk van God (Israel of die kerk) net bestaan omdat God dit so wil, omdat God deur verbondshandelinge die volk in aansyn roep. Die kerk bestaan nie op grond van die vrye keuse of wilsbesluit van mense nie, maar op grond van God se handelinge met die mens.

In Galasiërs 3:27 sê Paulus dat ons deur die doop met Christus verenig is. Hy voeg dan in vers 29 by: En as julle aan Christus behoort, is julle nakomelinge van Abraham. Dit is dus duidelik verbondsterminologie wat hy aanwend wanneer hy oor die doop praat. Daar is in hierdie gedeelte ook geen skerp skeiding tussen die ou en nuwe verbond nie. Dit word bevestig deur 'n gedeelte soos Kolossense 2:11-12, waar daar vir die Christene in Kolosse gesê word dat hulle in verbondenheid met Christus besny is - nie ' $n$ liggaamlike besnydenis nie, maar 'n besnydenis wat paasvind deurdat hulle sondes deur Jesus Christus weggeneem is. Hierdie besnydenis, het by die doop plaasgevind. Op hierdie wyse word die Ou-Testamentiese verbondshande- 
ling van die besnydenis direk aan die doop verbind. Ander teksgedeeltes waar verbondsterminologie gebruik word as daar oor die doop gepraat word, is onder andere Handelinge 2 en die sogenaamde "huisgesintekste". Die uitdrukking "hy en sy huisgesin" is tipiese verbondsterminologie.

Dit bly legitiem om in terme van die verbond oor die doop te redeneer, want dit is uit hierdie tekste duidelik dat (onder andere) die ou en nuwe verbond en besnydenishandeling as agtergrond van die doop gedien het. In die Ou Testament is daar twee maniere hoe 'n Israeliet deel word van die verbond: Hy het of as volwassene tot geloof gekom, is dan besny en het deel geword van die volk van God. Tweedens is die kinders van gelowige Israeliete op die agtste dag besny. Daarna is hulle deur die regte opvoeding en verkondiging tot ' $n$ ware geloof en bekering gelei. Soos die besnydenis in die Ou Testament die teken van die inlywing in die verbond en die volk van God was, so word die doop 'n sigbare bevestiging van en inlywing in die nuwe verbond en die kerk.

Die Heidelbergse Kategismus antwoord die vraag of jong kinders gedoop moet word, soos volg in Sondagsafdeling 27, Vraag 74:

$\mathrm{Ja}$, aangesien hulle net soos die volwassenes in die verbond van God en sy gemeente ingesluit is. Ook aan hulle word nie minder as aan die volwassenes deur die bloed van Christus die verlossing van die sondes en die Heilige Gees wat die geloof bewerk, beloof nie. Daarom moet hulle ook deur die doop as teken van die verbond in die Christelike kerk ingelyf en van die kinders van die ongelowiges onderskei word.

(NHKA 1983:186)

\section{DIE VERBAND TUSSEN DOOP EN LIDMAATSKAP VAN DIE KERK KERKREGTELIK BESKOU}

\subsection{Calvyn}

Volgens die Ordonannances Ecclesiastiques, wat deur Calvyn opgestel is en op 20 November 1541 in Genève van krag geword het (Pont 1981:21), was ouers verplig om hulle kinders te doop. Daar is streng opgetree teen mense wat die kinderdoop bestry het, byvoorbeeld die Anabaptiste. Volgens die Geneefse kerkorde moes al die kinders 
gedoop word, moes almal katkiseer en uiteindelik moes almal belydenis van geloof aflê.

Wat opvallend is, is dat die Geneefse kerkorde nêrens sê dat jy eers in die gemeenskap van die gelowiges opgeneem word met die aflê van die openbare belydenis van geloof nie. Inteendeel - dit word duidelik gestel dat lidmaatskap van die kerk volg op die doop as uiterlike teken van die genadeverbond. Dit word ook bevestig deur Calvyn se uiteensetting van die doop in sy Institusie. In Inst 4.15.1. (Sizoo se vertaling) sê Calvyn: De doop is een teken der inwijding, waardoor wij tot de gemeenschap der kerk worden aangenomen, opdat wij, in Christus ingeplant, onder Gods kinderen word gereken. Die doop is dus vir Calvyn 'n inisiasie in die kerk. Hierin sluit Calvyn baie nou by Luther aan (Wendel 1987:319). Die gebruik was dat die kinders so vroeg as die agtste dag na geboorte gedoop is, dikwels sonder dat die moeder teenwoordig was.

Nadat 'n kind gedoop is, het die kind opgegroei en as "hy of sy tot sy of haar verstand gekom het," het hy of sy begin katkiseer. Dit was een van die dinge waarop die Kerkhervormers baie meer as die Rooms-Katolieke Kerk klem gelê het. Wanneer die kind genoegsaam gekatkiseer het om die nagmaal te kan verstaan (gewoonlik op ouderdom 12), het die geloofsbelydenis gevolg. Die geloofsbelydenis het volgens die Geneefse kerkorde die funksie om aan katkisante die geleentheid te bied om in die openbaar te kenne te gee dat hulle instem met dit wat hulle geleer het uit die Woord van God, dat hulle instem met die leer van die kerk en genoegsame kennis en onderskeidingsvermoë het om nagmaal te kan gebruik. Hier is geen sprake daarvan dat lidmaatskap op die belydenis van geloof volg nie, eerder dat dit deel van die kerkraad se opsigtaak is om toe te sien dat die nagmaal nie ontheilig word nie. Mense is lidmaat van die kerk op grond van die genadeverbond, soos bevestig deur hulle doop. Die geloofsbelydenis dien geen funksie tẹn opsigte van lidmaatskap nie.

\subsection{Bucer}

Teenoor Calvyn het Bucer in sy kerkorde die geloofsbelydenis omskryf as 'n opname in die gemeenskap van die gelowiges (Pont 1991:440). Die latere kerkordes het Bucer se siening dat lidmaatskap op die geloofsbelydenis volg, behou. So vind ons byvoorbeeld in die kerkorde wat die Konvent van Wezel in 1568 opgestel het, dat daar in Artikel 48 gesê word: En voorwaar, alle die voor ledematen in de kerk 
gehouden willen worden, zullen zo haast de jaren der kinderen dit toelaten, zich laten catechiseeren ... (vgl Pont 1981:82).

Die gedagte dat jy eers lidmaat van die kerk word na katkisasie en die aflê van geloofsbelydenis word hierna in al die Nederlandse kerkordes voortgesit. Die nasionale sinode wat te Dordtdrecht in 1587 vergader het, het hierdie standpunt in Artikel 64 verder bevestig (Pont 1981:138). In hierdie kerkorde word baie duidelik uiteengesit dat die kind op grond van die verbond gedoop word, volwassenes word gedoop op grond van hulle geloofsbelydenis. In die geval van volwassenes volg. lidmaatskap direk op die doop, maar in die geval van kinders bly lidmaatskap uit tot en met die aflê van die geloofsbelydenis. Daar word dus onderskeid getref tussen die kindgedoopte en volwasse-gedoopte. Die volwasse-gedoopte is "ten volle" lidmaat van die kerk en kan nagmaal gebruik. Die kind-gedoopte is "voorlopig" lidmaat van die kerk. Dit. is hierdie gedagte wat deurloop tot in die vorige Kerkwet van die NHKA.

\subsection{Lidmaatskap in die vorige Kerkwet van die Nederduitsch Hervormde Kerk}

\subsubsection{Kerkbegrip in die Kerkwet}

Die vorige Kerkwet van die NHKA begrond die Kerk verbondsmatig. In Artikel 2 van die Kerkwet word bepaal dat ter wille van die goeie orde word almal wat deur die genadeverbond tot die Kerk behoort, byeengebring in gemeentes (NHKA 1989:1). In Artikel 16 van die Kerkwet word verder gesê dat die doop bedien word aan die kinders van die verbond. Deur die kerk verbondsmatig te begrond, word die idee van 'n vryekerk afgewys. Dit is dus nie die individu wat by geleentheid besluit om deel te wees van die kerk nie, maar God wat deur die verbond die kind in die kerk opneem. Daarom funksioneer die doop as die uiterlike teken van die genadeverbond, en tegelykertyd ook as die uiterlike teken van die opname in die kerk (Van Wyk 1991:247). Die kerkbegrip wat in sommige artikels van die Kerkwet na vore kom, is dat die kerk nie gekonstitueer word deur die individu wat belydenis van geloof aflê en dan lidmaat van die kerk word nie; of op die individu wat wedergebore is en daarom in die kerk opgeneem word nie; of op die individu wat met sy of haar eie wilsbesluit toetree tot die kerk nie.

Die belydenisskrifte begrond die kerk op die uitverkiesing. Die Nederlandse Geloofsbelydenis sê in Artikel 16 dat God is barmhartig, aangesien Hy die wat Hy 
uitverkies het, uit die verderf trek en verlos; God het hulle, uit louter goedheid en sonder om hulle werke in die minste in aanmerking te neem, in sy ewige en onveranderlike raad uitverkies in Jesus Christus onse Here (NHKA 1983:157). Die Heidelbergse Kategismus sê in Sondagsafdeling 21, Vraag 54, dat die Seun van God uit die hele menslike geslag vir Hom 'n gemeente wat tot die ewige lewe uitverkies is, deur sy Gees en Woord in die eenheid van die ware geloof ... vergader ... (NHKA 1983: 181). Die Dordtse Leerreëls stel in punt 17: Die Woord van God ... getuig daarvan dat die kinders van gelowiges heilig is. Hulle is nie van nature heilig nie, maar kragtens die genadeverbond waarin hulle saam met hulle ouers opgeneem is (NHKA 1983:223). Die gemeenskaplike hierin is dat die oorsprong van die verbond en die kerk in God se uitverkiesende genade lê. Die kerk word nie gebou op menslike besluit en willekeur nie, maar op die dade van God.

\subsubsection{Lidmaatskap in die 1997-Kerkwet van die NHKA}

Lidmaatskap van die NHKA word kerkordelik gereël in Artikel 3 van die Kerkwet. Artikel 3 stel (NHKA 1989:1) dat persone lidmaat van die Kerk is wat:

- In die gemeenskap van die Kerk opgeneem is deur die doop;

- Deur belydenis van geloof lidmaat geword het van die kerk;

- Kinders van lidmate van die kerk is.

Daar word in hierdie artikel onderskei tussen gedoopte lidmate, belydende lidmate en lidmate wat nie gedoop is of belydenis van geloof afgelê het nie, maar op grond van hulle geboorte uit gelowige ouers gereken word as lidmate van die kerk. Die teologiese agtergrond van die derde is die genadeverbond, wat God se genade nie individualisties aan enkelinge verbind nie, maar met die gelowige gesin werk as basiese bousteen van God se verbond met die mens. Die veronderstelling is dat hierdie derde kategorie lidmaat klein kindertjies sal wees, omdat ouers volgens die Kerkwet onder die verpligting staan om hulle babas ten doop te hou. Solank as wat die babas nog nie gedoop is nie, is hulle reeds op grond van hul ouers se geloof lidmate van die kerk.

Artikel 16 van die Kerkwet vermeld die doop sonder om iets te sê oor lidmaatskap. Artikel 17 handel oor die kategese, en stel dat die kategese moet lei tot 'n 
openbare belydenis van geloof, die gebruik van die sakramente en verantwoordelike lidmaatskap van die kerk. Hierdie artikel skep die indruk dat lidmaatskap van die kerk eers 'n werklikheid word na belydenis van geloof. Hierdie indruk word bevestig deur Artikel 18 van die Kerkwet waar gepraat word oor die openbare belydenis van geloof. In die Artikel word uitdruklik gesê dat jy in die gemeente opgeneem word met die aflê van geloofsbelydenis, en dan, op grond van die lidmaatskap van die Kerk, nagmaal kan gebruik. Daar is dus teëspraak tussen Artikel 3 en 18 van die Kerkwet, aangesien Artikel 3 sê dat jy reeds by jou doop, en selfs as ongedoopte, lidmaat van die kerk is en Artikel 18 sê jy word in die gemeenskap van die gelowiges opgeneem met aflegging van geloofsbelydenis. Is daar 'n verskil tussen die kerk en die gemeenskap van gelowiges?

Om die saak verder te kompliseer bepaal die Kerkwet dat die dooplidmaat onder die opsig van die kerkraad staan - met ander woorde daar word van die dooplidmaat verantwoordelike lidmaatskap verwag (Artikel 17). Daar word gesê dat die dooplidmaat verantwoordelik is om kategese by te woon, Bybel te lees en te bid, die erediens by te woon en 'n Christelike lewe te lei.

Uit bogenoemde voorbeelde is dit duidelik dat daar in die vorige Kerkwet van die NHKA nie op 'n eenvormige wyse oor lidmaatskap gepraat het nie, en dat daar selfs 'n mate van spraakverwarring was.

\subsection{Die verband tussen doop en lidmaatskap in die Kerkorde (1 Januarie 1998) van die Nederduitsch Hervormde Kerk van Afrika}

In die nuwe Kerkorde van die NHKA, word die kerk, en daarmee saam die hele saak van lidmaatskap, op die uitverkiesing begrond. In Ordereël 1 word gestel:

Die kerk is 'n gemeenskap van gelowiges wat God deur sy versoening in Christus tot stand bring en in stand hou, deurdat Hy mense in Jesus Christus in genade uitkies en deur die werk van die Heilige Gees saambring om deur die Woord en sakramente 'n heilige volk te wees, en dienswerk in die wêreld te verrig.

Uit hierdie formulering word dit alreeds duidelik dat die sakramente ter sake is as daar oor lidmaatskap van die kerk gepraat word. In Ordereël 4.1. word oor lidmaatskap gestel: 
Almal wat deur God in genade geroep is en deur die Heilige Gees in Jesus Christus glo, is lede van sy liggaam. Lidmate van 'n gemeente is diegene wat kinders van die lidmate van die gemeente is; in die gemeente gedoop is; deur belydenis van geloof lidmate van die gemeente geword het; uit ander gemeentes en kerke deur die ouderlingevergadering toegelaat is.

Uit hierdie formulering is dit duidelik dat die Hervormde Kerk steeds un gudagte handhaaf dat die doop nie die enigste voorwaarde vir lidmaatskap van die Hervormde Kerk is nie. Die doop bly steeds 'n voorlopige lidmaatskap, wat eers bevestig word wanneer die gedoopte in die openbaar voor die gemeente belydenis van geloof aflê.

\section{GEVOLGTREKKINGS}

Met al bogenoemde in gedagte, moet daar dalk die volgende oorweeg word ten opsigte van lidmaatskap van die Nederduitsch Hervormde Kerk van Afrika:

- Op grond van die genadeverbond word alle kinders van lidmate van die Nederduitsch Hervormde Kerk van Afrika gedoop, en só in Christus ingelyf en as lidmaat in die Hervormde Kerk opgeneem.

- Daar word van al die lidmate van die Kerk (dws gedooptes) verwag om gereeld erediens by te woon, 'n Christelike lewe te lei, volgens vermoë die voorgeskrewe kategeseprogram van die Hervormde Kerk te deurloop, by geleentheid openbare belydenis van geloof af te lê en daarna gereeld nagmaal te gebruik.

- Wanneer lidmate van ander kerke aansoek doen om lidmaatskap van die Nederduitsch Hervormde Kerk van Afrika, stel die ouderlingevergadering vas of die persoon gedoop is in die Naam van die Vader, Seun en Heilige Gees. Indien die persoon wel só gedoop is, word hy of sy aanvaar as lidmaat van die Hervormde Kerk. Die ouderlingevergadering kan dan bepaal of sodanige persoon nog moet katkiseer, belydenis van geloof moet aflê en wanneer hy of sy mag nagmaal gebruik (dit sluit direk aan by die bepaling in die nuwe Kerkorde, waar in Ordinansie 4.3 gestel word dat die ouderlingevergadering 'n persoon aanvaar as lidmaat, en dan besluit oor verdere kategese, toerusting en of die persoon belydenis van geloof moet aflê). 
- Wanneer 'n buitekerklike deur middel van evangelisasie sover gebring word om Jesus Christus as Verlosser te bely, word hy of sy op grond van die belydenis gedoop en as lidmaat van die Hervormde Kerk aanvaar. Daarna deurloop die persoon verdere kategese. Die kerkraad bepaal op watter stadium die persoon nagmaal mag gebruik.

- In die geval van verhuising na ander gemeentes van die Hervormde Kerk of ander kerke, word 'n bewys van lidmaatskap uitgereik vir elke lidmaat (dws gedooptes), waarop vermeld word of die lidmaat reeds gekatkiseer het, belydenis van geloof afgelê het en deur die kerkraad toegelaat is om nagmaal te gebruik.

\subsection{Kommentaar}

Deur lidmaatskap op hierdie wyse te reël, word erkenning gegee aan die volgende sake:

- Die genadeverbond en doop is die manier hoe iemand deel word van die kerk. Inderdaad is daar geen teoloog wat nie sal saamstem dat die doop wesenlik belangrik is vir ons verstaan van die kerk en lidmaatskap van die kerk nie. Dit is my mening dat 'n persoon wat gedoop is, reeds "ten volle" lidmaat van die kerk is. Dit is nie nodig om dit nog te bevestig met ' $n$ belydenis van geloof nie. Daarmee word die openbare belydenis van geloof nie ongedaan gemaak nie, maar kry dit ' $n$ ander betekenis - dit is ' $n$ geleentheid waar die lidmaat in die openbaar antwoord op sy of haar doop, en die ouderlinge van die gemeente die geleentheid het om vas te stel of die lidmaat soos en saam met die kerk glo en bely. Dit het dus (soos by Calvyn) 'n opsighoudende funksie, en nie ' $n$ funksie ten opsigte van lidmaatskap nie.

- 'n Kind van gelowige ouers wat nie gedoop is nie, leef onder die genadeverbond. Daar word onder die opsig gehandel met ouers wat nie hulle kinders laat doop niel

- Die doop is van kardinale belang vir elke gelowige, en die kerk moet aan die die doop reg laat geskied.

- Die kerk is nie 'n vrye vereniging nie, maar die volk van God en die liggaam van Christus. 
- Die eenheid van die kerk is belangrik (daar is net één Here, één Gees en één doop).

- Die ouderlingevergadering moet opsig uitoefen oor lidmate van hulle geboorte tot by hulle dood. Dit is ook die kerkraad wat moet toesien dat lidmaatskap ordelik gereël word.

- Klem word geplaas op die bearbeiding van die kind in die gemeente, deurdat die kind as gedoopte lidmaat van die Kerk begelei word tot 'n volwasse geloof, deur middel van die erediens, kategese en pastoraat. Die kind ontvang só die nodige aandag binne die gemeentelike opset.

- Daar is geen dwang om openbare belydenis van geloof af te lê om "lidmaat te word" nie. Na die kategeseprogram dui gedooptes self aan wanneer hulle gereed is om openbare belydenis van geloof af te lê. Dit beteken dat die erediens, pastoraat en kategetiese onderrig nie net blote kennis moet bybring nie, maar ook die hart en gesindheid van kinders moet raak en verander, sodat hulle met oortuiging belydenis van geloof kan aflê. Die beskuldiging dat kinders outomaties deur die kategese na die belydenis beweeg, sonder dat hulle noodwendig reg is daarvoor, word ondervang. Dit plaas ook die verantwoordelikheid op die kerkraad om toe te sien dat daar voortgaande bearbeiding plaasvind indien 'n persoon nie gereed sou wees vir 'n openbare belydenis van geloof nie.

- Die verbondsgesin is baie belangrik. Die kern van die Hervormde Kerk bly gelowige huisgesinne, waar elke nuwe lid van die huisgesin (kind) deur die doop in die huisgesin van God opgeneem word.

- Evangelisasie kan daardeur bevorder word. Nadat 'n persoon deur die doop in die kerk gegelyf is, volg 'n toerustingsprogram wat meelewendheid bevorder. Dit is opvallend dat in die Nuwe Testament (veral in die boek Handelinge) die volgorde doop > leer hulle is. In die kerklike tradisie het dit egter omgeswaai na leer hulle $>$ doop. Partymaal verloop daar 'n hele tyd nadat iemand tot geloof gekom het voordat hy gedoop word en as lidmaat van die kerk gereken word. Dit lei dikwels daartoe dat die persoon belangstelling verloor. Die vroegste kerk het net een voorwaarde geken om gedoop te word en in die kerk opgeneem te word, en dit is die geloof in God en die belydenis dat Jesus Christus die Here en Verlosser is (König 1995:38-39). Dit is dieselfde 
beginsel wat toegepas word op 'n kind wat gedoop word - eers doop en dan volg die kategetiese onderrig op 'n later stadium. Die onderrig is eintlik 'n lewenslange proses (o a deur die erediens) wat vir alle gedooptes geld - ook hulle wat as kindertjies gedoop is.

\section{Literatuurverwysings}

Calvyn, J 1559. Institusie, Deel III. Vertaling deur A Sizoo. Tweede druk 1949. Delft: Naamloze Vennootschap W D Meinema.

Dreyer, W A 1986. Sakramente/Doop/Nagmaal, in Glo die Woord. Pretoria: Kital. König, A 1995. Stof jou doop af! Kaapstad: Lux Verbi.

Linnemann, E \& Perrin, N 1983. Taufe und Kinderzugehörigkeit. München: Chr. Kaiser.

Nederduitsch Hervormde Kerk van Afrika 1989. Kerkwet en Bepalings. Pretoria: Kital.

Nederduitsch Hervormde Kerk van Afrika 1983. Diensboek, Pretoria: Kital

Nederduitsch Hervormde Kerk van Afrika 1995. Kerkorde. Uitgegee deur die 65e Algemene Kerkvergadering.

Osborne, K B 1987. The Christian sacraments of initiation - baptism, confirmation and eucharist. New York: Paulist Press.

Pelser, G M M s a. Die doop in die Nuwe Testament. Ongepubliseerde klasaantekeninge, Departement Nuwe-Testamentiese Wetenskap, Universiteit van Pretoria.

Pont, A D 1981. Historiese agtergronde van ons kerklike reg, Deel 1. Pretoria: HAUM.

- 1991. Historiese agtergronde van ons kerklike reg, Deel 2. Pretoria: HAUM.

- 1991. Kategese, kategismusse en die belydenis van geloof. $H T S, 47(2)$.

Pont, A D s a. Die kinderdoop en verbond. Ongepubliseerde klasaantekeninge, Departement Kerkgeskiedenis en Kerkreg, Fakulteit Teologie. Universiteit van Pretoria.

Pope, M H 1985. Proselyte, in Buttrick, G A (ed). International Dictionary of the Bible, 3. Nashville: Abbingdon Press.

Van't Spijker, W (red) 1983. Rondom de doopvont. Kampen: Uitgeverij De Groot Goudriaan. 
Die verband tussen doop en lidmaatskap van die kerk

Van Wyk, B J 1991. Die presbiteraal-sinodale kerkbegrip. Pretoria: Kital.

Venter, P M 1984. Verbondsteologie - 'n tendensstudie. HTS 40(4).

Wendel, F 1978. Calvin. London: Collins. 